\title{
A Study on Brand Impact of Apparels on Consumer Buying Behaviour in Kukatpally Area
}

\author{
Dr. R. Narsaiah¹, R Shashi Preetham² \\ ${ }^{1}$ Assistant Professor, Department of Humanities and Social Sciences, ${ }^{2}$ Student \\ 1,2Jntuh College of Engineering, Hyderabad, Telangana, India
}

\begin{abstract}
How to cite this paper: Dr. R. Narsaiah | R Shashi Preetham "A Study on Brand Impact of Apparels on Consumer Buying Behaviour in Kukatpally Area" Published in International Journal of Trend in Scientific Research and Development

(ijtsrd), ISSN: 2456-

6470, Volume-3 |

Issue-3 , April 2019,

pp.514-517, URL:

http://www.ijtsrd.co

$\mathrm{m} /$ papers/ijtsrd228

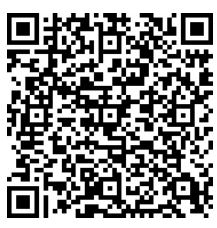

IITSRD22838
\end{abstract}

38.pdf

Copyright (C) 2019 by author(s) and International Journal of Trend in Scientific Research and Development Journal. This is an Open Access article distributed under the terms of the Creative Commons Attribution License (CC BY 4.0) (http://creativecommons.org/licenses/ by/4.0)

\section{INTRODUCTION}

The purchasing process is a combination of mental and physical activities that ends with an actual purchase. Therefore it is interesting to study the connection with in what and why we buy it. In this circumstance, brands play a main role in consumer decision making. There are many factors of consumers effecting their opinions and decisions. In today's increasing competitive marketplace, Consumers differ in their perceptions; they would necessarily hold different images for any specific apparel brand and often have to make a choice among a range of apparel brands in the market that differ very little in its price. In such circumstances, their final decision depends on the image they have with different brands. All the study has been conducted with reference to apparels industry. Firms in apparels industry are competing to increase their profit share in the market and among these firms; branded clothing has shifted the conventional style and interest of people. A brand is sold at a high price and the other is sold at low price while both have same quality and attributes, why is that? Brand studies always remained the key attention of the marketers because of its importance and direct relationship with consumers. Marketers use brands as to get the competitive advantage on other competitors playing an imperative role in the success of companies. Brand holds a great importance in consumer's life. Consumer's choose brands and trust them the way they trust their friends and family members to avoid uncertainty and quality related issues. India has a successful growing economy and the clothing industry of the country has grown tremendously in the recent years. The increasing use of branded apparels and the emerging market has intrigued foreign as well as local brands to provide services to its customers.

\section{OBJECTIVES OF THE STUDY}

The main objectives of the study are:

1. To study the demographics of the respondents with their preferences towards attributes of branded apparels

2. To study the frequency of buying branded apparels of the respondents with their income levels.

3. To study the gender preferences with respect to influence of branded apparels on them.

4. To study how respondents get to know about a particular apparel brand.

\section{REVIEW OF LITERATURE}

According to Aaker (2004), in brand equity consumer only makes purchase to same brand regardless of the demonstrated benefits. Consumer loyalty means a brand has a very strong position in the market and the chances of consumers to switch another brand becomes low and consumers are willing to purchase the same brand, they want to invest money in that particular brand. 
According to Keller (2003), the fact that consumers purchase the same brand continuously is not brand loyalty. They just do it because of their common habits that don't change or they are being attracted by purchase offers or any other promotional tool.

According to Driessen (2005), companies can create strong brand image and recognition through advertisement. He explained that by advertisement, companies try to target teenagers and youth. They are attracted towards traditional advertisement more easily than adults those who are mature. They show positive reaction and quick reaction to the company's advertisement. Older person has more purchasing experience than younger one.

\section{METHODOLOGY}

This study is based on the primary data collected through a sample of 128 people. The questionnaire was constructed to understand the impact of branded apparels on consumer buying behaviour. The data was collected through a survey along with the detailed demographics of the participants. Secondary data was collected from various sources such as books, journals, and online resources. This questionnaire was distributed to 128 people in Kukatpally area. So the final sample size is 128 . The questionnaire was sent by e-mail and What's app contacts in the form of Google forms. The completed questionnaire was sent back through email and responses were updated in Google forms. Hyderabad is a place where we can see people with different cultures and customs. Since Hyderabad is technically developed, research is conducted in this area. It is conducted using quantitative as well as qualitative method. Quantitative data is collected with the help of questionnaire. The data collected from the questionnaire is analysed using the mathematical tools and the result is presented in tables for clear understanding to the reader. The conclusions are drawn from the findings. The collected data are logically and systematically entered using SPSS software and analysis done as per the requirement of study. Descriptive analysis is done for analysing the data. Central tendency, frequency table, Chart, Graph and Chisquare are used for descriptive analysis. Whereas Hypothesis testing, Chi-square test, t-test are done for internal analysis.

\section{RESEARCH HYPOTHESIS}

1. Null Hypothesis (H0): There is no significant association between age and attributes while selecting branded apparel.

Alternative Hypothesis (H1): There is a significant association between age and attributes while selecting branded apparel.

2. Null Hypothesis (H0): There is no significant association between income of the respondents and frequency of buying branded apparels.

Alternative Hypothesis (H1): There is a significant association between earnings of the respondents and frequency of buying branded apparels.
3. Null Hypothesis (H0): There is no difference between male and female groups with respect to influence of branded apparels on buying behaviour.

Alternative Hypothesis (H1): There is a difference between male and female groups with respect to influence of branded apparels on buying behaviour.

\section{DATA ANALYSIS AND INTERPRETATION}

\section{Age \\ 6.1 Demographic profile of respondents}
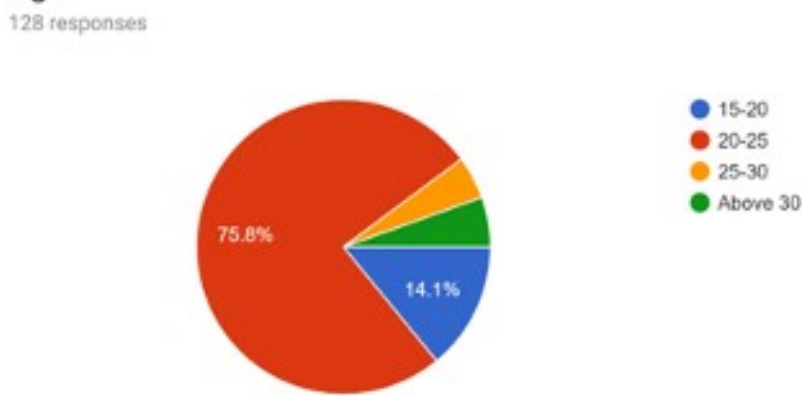

Figure 1: Age analysis

Gender
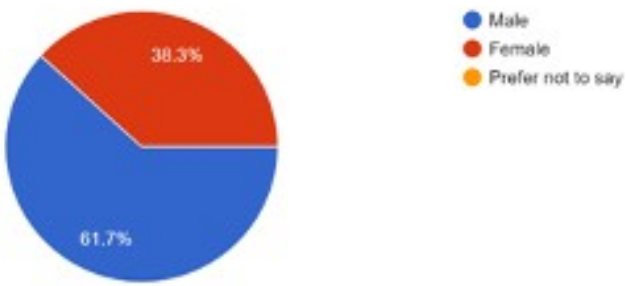

Figure 2: Gender analysis

a. Descriptive statistics:

a. Descrip
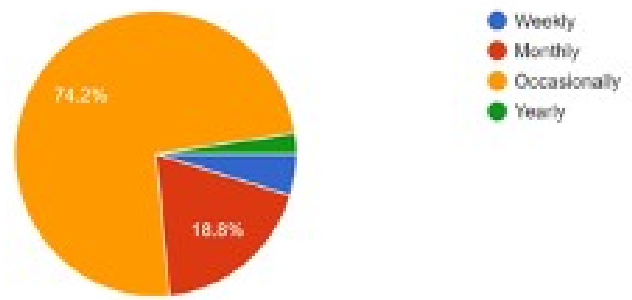

Figure 3: Frequency of buying

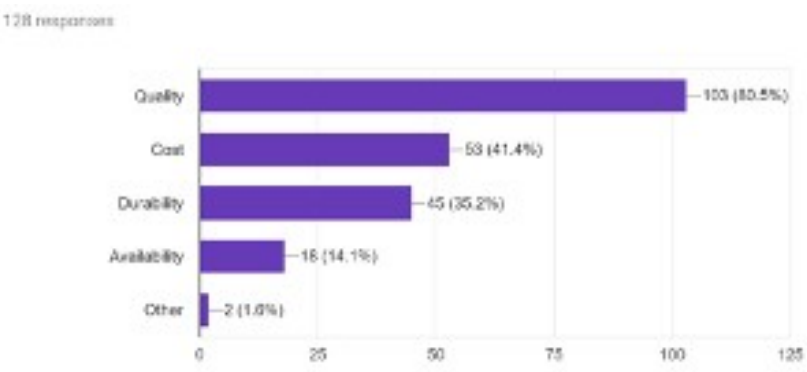

Figure 4: Attributes of respondents while choosing a branded apparel 
International Journal of Trend in Scientific Research and Development (IJTSRD) @ www.ijtsrd.com eISSN: 2456-6470

\subsection{Cross tabulation analysis}

6.2.1 Cross tabulation of age and attributes while selecting a branded apparel

\begin{tabular}{|c|c|c|c|c|c|}
\hline \multirow{2}{*}{ Attributes while selecting a branded apparel } & \multicolumn{4}{|c|}{ Age } & \multirow{2}{*}{ Total } \\
\hline & $15-20$ & $20-25$ & $25-30$ & Above 30 & \\
\hline Quality & 16 & 77 & 4 & 7 & 104 \\
\hline Cost & 12 & 58 & 3 & 3 & 76 \\
\hline Durability & 6 & 59 & 4 & 3 & 72 \\
\hline Availability & 6 & 36 & 1 & 3 & 46 \\
\hline Total & 18 & 97 & 6 & 7 & 128 \\
\hline
\end{tabular}

Table 1: Cross Tabulation of age and attributes While selecting a branded apparel

6.2.2 Cross tabulation of income of respondents and frequency of their buying branded apparels

\begin{tabular}{|c|c|c|c|c|c|}
\hline \multirow{2}{*}{ Income level } & \multicolumn{4}{|c|}{ Frequency of buying } & \multirow{2}{*}{ Total } \\
\cline { 2 - 5 } & Monthly & Occasionally & Weekly & Yearly & \\
\hline Less than 15000 & 2 & 19 & 0 & 1 & 22 \\
\hline $15000-20000$ & 0 & 7 & 0 & 0 & 7 \\
\hline $20000-50000$ & 4 & 12 & 2 & 0 & 18 \\
\hline Greater than 50000 & 8 & 8 & 0 & 0 & 16 \\
\hline No income & 10 & 49 & 4 & 2 & 65 \\
\hline Total & 24 & 95 & 6 & 3 & 128 \\
\hline
\end{tabular}

Table 2: Cross tabulation of income of respondents and frequency of their buying branded apparels

\section{b. Chi square analysis}

6.3.1 Analysis of age and attributes while selecting branded apparels

Here, the analysis covers all the statistical analysis made to verify the hypothesis and ascertain the significance of age and attributes while selecting branded apparels.

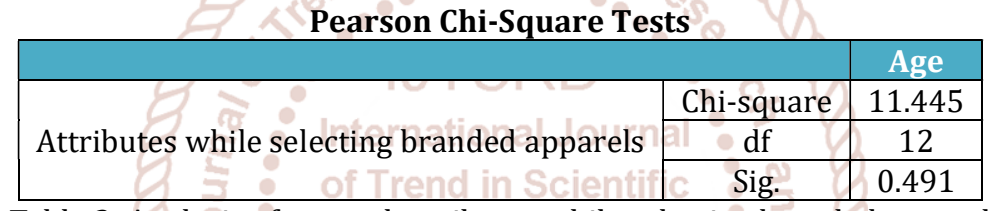

Table 3: Analysis of age and attributes while selecting branded apparel

We can see that as the chi- square value (0.491) is greater than 0.05 level of significance. Therefore we accept the null hypothesis and we can conclude that there is no significant association between age and attributes while selecting branded apparel.

\subsubsection{Analysis of income of respondents and frequency of their buying branded apparels}

Here, the analysis covers all the statistical analysis made to verify the hypothesis and ascertain the significance of income of respondents and frequency of their buying branded apparels

\begin{tabular}{|c|c|c|c|}
\hline & Value & df & Asymptotic Significance (2-sided) \\
\hline Pearson Chi-Square & 19.285 & 20 & 0.046 \\
\hline Likelihood Ratio & 20.808 & 20 & 0.049 \\
\hline N of Valid Cases & 128 & & \\
\hline
\end{tabular}

Table 4: Analysis of income of respondents and frequency of their buying branded apparels

We can see that as the chi- square value (0.046) is less than 0.05 level of significance. Therefore, we reject the null hypothesis and accept alternate hypothesis. Hence, we can conclude that there is a significant association between income of respondents and frequency of their buying branded apparels.

\subsection{Independent t- test}

6.4.1 Analysis of the gender and influence of apparels brand on buying behaviour

Here, the analysis covers all the statistical analysis made to verify the hypothesis and ascertain the significance of gender and influence of apparels brand on buying behaviour.

\section{Group statistics}

\begin{tabular}{|l|c|c|c|c|c|}
\hline & Gender & $\mathrm{N}$ & Mean & Std. Deviation & Std. Error Mean \\
\hline \multirow{2}{*}{ Influence of apparels brand on buying behavior } & Male & 79 & 1.608 & 0.4914 & 0.0553 \\
\cline { 2 - 6 } & Female & 49 & 1.673 & 0.4738 & 0.0677 \\
\hline
\end{tabular}

Table 5: Group statistics 
International Journal of Trend in Scientific Research and Development (IJTSRD) @ www.ijtsrd.com eISSN: 2456-6470

\begin{tabular}{|c|c|c|c|c|c|c|c|c|}
\hline & & \multicolumn{2}{|c|}{$\begin{array}{l}\text { Levene's Test for } \\
\text { Equality of Variances }\end{array}$} & \multicolumn{5}{|c|}{ t-test for Equality of Means } \\
\hline & & F & Sig & $t$ & df & $\begin{array}{c}\text { Sig. } \\
\text { (2 tailed) }\end{array}$ & $\begin{array}{c}\text { Mean } \\
\text { difference }\end{array}$ & $\begin{array}{l}\text { Std. error } \\
\text { difference }\end{array}$ \\
\hline \multirow{2}{*}{$\begin{array}{l}\text { Influence of } \\
\text { apparels } \\
\text { brand on } \\
\text { buying } \\
\text { behaviour }\end{array}$} & $\begin{array}{c}\text { Equal variances } \\
\text { assumed }\end{array}$ & 2.409 & 0.123 & -747 & 126 & 0.456 & -.0659 & 0.0882 \\
\hline & $\begin{array}{l}\text { Equal variances } \\
\text { not assumed }\end{array}$ & & & -754 & 104.729 & 0.453 & -.0659 & 0.0874 \\
\hline
\end{tabular}

Table 6: Independent samples test

As we can see from the Table 6 , the p- value is 0.456 which is greater than 0.05 . Thus, the null hypothesis is accepted and we can conclude that there is no difference among male and female groups with respect to influence of branded apparels on them.

\section{CONCLUSIONS}

In this study there are some research limitations with regard to the convenience sampling as the number of respondents is restricted to only Kukatpally. Hence, it may not be a perfect representation of the population. Furthermore, there is a chance of response errors due to many factors such as misinterpretation, hesitation, unawareness and so on among the respondents. The study shows that apparels brand has an influence on buying behaviour of the consumers. The paper also concludes that independent of age, attributes preferred by consumers are same. It also concludes that income of consumers affect frequency of their buying branded apparels. From this paper, we can also see that independent of gender, both male and female groups are influenced by brand of apparels. From this paper, it was found that advertisements play a major role in making consumers know about a branded apparel. It was also concluded that consumers feel more comfortable and satisfied in purchasing the branded apparels they already experienced.

\section{REFERENCES}

[1] Bengtsson, A. (2002). Consumer and mixed brands- on the polysemy of brand meaning, KFS AB Lund.

[2] Bernard, H. R. (2011). Research methods in anthropology: Qualitative and quantitative approaches: Altamira press.

[3] Aaker, J.L., "Dimensions of brand personality", Journal of Marketing Research, vol. 34, pp. 347-56, 1997.

[4] Keller, K., 'Conceptualizing, measuring, and managing customer-based brand equity', Journal of Marketing, vol. 57, pp. 1-22, 1993.

[5] Gajjar., "Factor affecting consumer behavior", vol. 1, no. 2, April, 2013.

[6] Moor-Shay, E. S., Intergenerational influences in the formation of consumer attitudes and beliefs about marketplace: Mothers and Daughters', Advances in Consumer Research, vol. 15, pp. 461-467, 1988.

[7] Kilsheimer, J., 'Status Consumption: The Development and Implications of a Scale Measuring the Motivation to Consume for Status', a dissertion submitted to the Marketing Faculty at Florida State University, FL, 1993.

[8] Shermach, K., 'What consumers wish brand managers knew', Marketing News, vol. 31, no. 12, 9th June, 1997.

[9] Beri G.C. (2008) 'Marketing Research' 4th Edition Tata Mc-Graw Hill company 